\title{
1
}

\section{O lugar da ética na reposição da questão do ser}

\author{
A história do ser sustenta e determina cada condition \\ e situation humaine. (Heidegger, Sobre o Humanismo)
}

Pretendemos mostrar, neste primeiro momento de nosso trabalho, a conexão existente entre o modo heideggeriano de pensar a questão do ser e a ética.

Iniciaremos apontando uma articulação entre ontologia e ética em Heidegger e, após uma breve explanação das principais críticas do autor de Ser e tempo à metafísica tradicional, passaremos a discorrer sobre os movimentos essenciais da pergunta pelo ser - na primeira e na segunda fase do pensamento heideggeriano - tentando aí vislumbrar uma possível ética. Prosseguiremos na direção de tornar manifesto que o modo como Heidegger interroga o ser, pode levar à compreensão de uma nova ética, uma "meta-ética". 


\subsection{A RELAC̣ÃO ENTRE ONTOLOGIA E ÉTICA}

O que é o ser? Eis a grande preocupação da filosofia desde o seu nascimento com os gregos. É a pergunta que busca por um "sentido objetivo" para a vida do homem e para a natureza, levando-nos à indagação por um "porquê" e "para quê" de tudo que existe. Colocar um "porquê" e "para quê" conduz-nos a uma outra questão: qual a relação entre a metafísica ${ }^{12}$ e a ética ${ }^{13}$ ?

12 A primeira referência que se conhece do título $\mu \varepsilon \tau \alpha \tau \alpha$ $\varphi v \sigma \iota \kappa \alpha$ encontrase em Nicolau de Damasco na primeira metade do século I d.C. Corresponde à principal obra de Aristóteles: "Há uma ciência que estuda o Ser enquanto ser". (ARISTOTE, Métaphysique. Traduction et Notes par J. Tricot. Paris: Vrin, 2000. t. 1, livre Г, 1,1003 a, 21). A denominação surgiu pela ordem dos escritos de Aristóteles publicados por Andrônico de Rodes no século I a.C. Metafísica refere-se aos escritos que foram colocados logo após os escritos da Física. Segundo Aubenque a ordem dos escritos na edição de Andrônico não segue uma organização meramente extrínseca sem significação filosófica. Estudos mais recentes demonstram que as listas antigas das obras de Aristóteles seguem uma classificação sistemática inspirada, em parte, em indicações do Estagirita. (AUBENQUE, Pierre. Le Problème de l'Être chez Aristote. 2. ed. Paris: PUF, 1994. p. 29). Não foi, portanto, uma feliz coincidência (como é pensado por muitos) que aquela ciência que estuda o que está além da física, além do sensível, tenha sido ordenada por Andrônico após os estudos físicos.

13 Antes de qualquer coisa, convém retomarmos a etimologia da palavra "ética" e sua relação com a "moral". O vocábulo "ética" apresenta na língua grega duas grafias: ethos ( $\uparrow \vartheta \circ \varsigma$ ), com eta, designando costumes de uma sociedade e ethos ( $\varepsilon \vartheta \circ \varsigma$ ), com epsilon, significando o comportamento do homem regido por estes costumes. Já a palavra "moral" procede do latim mos (pl. mores), também indicando hábitos. Ambos os termos, pois, historicamente, têm o mesmo sentido nas duas línguas e estão relacionados ao mesmo objeto, ou seja, aos costumes que vigoram na sociedade e aos hábitos do indivíduo de se comportar de acordo com os costumes socialmente aceitos. Vaz assinala que entre os gregos, mais especificamente em Aristóteles, o termo ética é usado indistintamente, referindo-se ao indivíduo isoladamente ou no contexto da pólis. Modernamente, o vocábulo moral ficou ligado à praxis individual, cabendo à palavra ética uma abrangência no âmbito da praxis social. No entanto, alguns autores, como o próprio Vaz, preferem usá-los indistintamente. Para ele, a dúvida quanto ao matiz semântico de ética e moral parece 
Na escola de Platão, pela primeira vez, a "Ética" surge ao lado da "Lógica" e da "Física" como disciplinas. É o momento em que esses conteúdos passam a ser pensados "disciplinadamente", isto é, passam a ser sistematizados no âmbito do pensamento e, dessa forma, o próprio pensar é também sistematizado. Como Heidegger afirma, "As disciplinas surgem ao tempo que permite a transformação do pensar em 'Filosofia', a Filosofia em epistéme (Ciência) e a Ciência mesma em um assunto de escola e de atividade escolar"14.

Assim, para Heidegger, antes de qualquer pergunta sobre a relação entre "ontologia" e "ética" como disciplinas acadêmicas, importa uma questão mais radical que é saber se o que é designado pelos termos "ontologia" e "ética" corresponde ou chega perto daquilo que é a tarefa do pensamento: pensar a verdade do ser. Nosso Filósofo assinala que,

O pensar que questiona a verdade do ser e nisto determina o lugar essencial do homem, a partir do ser e em direção a ele, não é nem Ética nem Ontologia. Por isso a questão da relação de ambas entre si não possui mais chão neste âmbito. E, contudo, sua pergunta, pensada mais originariamente, retém um sentido e um peso fundamentais ${ }^{15}$.

O que Heidegger quer com isto dizer é que o "pensamento do ser" deve ser prioritário em relação ao "pensamento conceitual" ou à organização de "saberes", como a Ética, a Lógica, a Física e outras disciplinas. Ele chega a afirmar que antes da Academia platônica não se conhecia nenhuma disciplina filosófica chamada Ética, Lógica ou Física e, nem por isso, o pensamento daquela época era imoral ou

decorrer desde os tempos de Kant, acentuando-se com Hegel ao fazer uma distinção entre Moralität e Sittlichkeit em Filosofia do Espírito Objetivo, em que Moralität estaria relacionada à moralidade interior preconizada por Kant e Sittlichkeit, ao campo clássico da eticidade social e política. Para um estudo mais aprofundado, Cf. LIMA VAZ, H. C. op. cit. p. 11-28.

14 HEIDEGGER, M. Sobre o Humanismo. p. 368.

15 HEIDEGGER, M. Sobre o Humanismo. p. 369 e 370. Aqui, Heidegger se refere à pergunta que Jean Beaufret lhe faz sobre a relação entre ontologia e ética. (Grifos nossos). 
ilógico. Heidegger exemplifica dizendo que a physis, em relação à Física posterior, nunca foi tão genuinamente pensada e que as lições de Aristóteles sobre Ética não carregam o ethos de modo mais originário do que aquilo que se encontra oculto nas tragédias de Sófocles. “(...) os nomes como 'Lógica', 'Ética', 'Física', apenas surgem quando o pensar originário chega ao fim. Em sua gloriosa era, os gregos pensavam sem tais títulos"16.

Pensar a verdade do ser significa, para Heidegger, o mesmo que pensar a humanitas do homo humanus, no entanto, sem o sentido metafísico de "humanismo", o que pressupõe: longe de preocupações éticas que, munidas de "instruções práticas", giram na órbita de "valores", isto é, no âmbito da metafísica da subjetividade, do pensamento que representa, que objetiva ${ }^{17}$. Para o "filósofo do ser", o "valor" ou o "valorar" está ligado a uma subjetivação; o ato de "valorar" de modo algum "deixa que o ente seja", mas, leva em conta apenas o "ente como objeto de seu operar"18. O que entra em jogo na valoração é simplesmente o que um objeto é para um sujeito ${ }^{19}$, isto é, o que ele é em sua "presença-constante". É por esse motivo, considera Heidegger, que "o pensar através de valores" é, em todo o caso, "a maior blasfêmia que se pode pensar em face do ser"20. Isto, entretanto, não deve ser entendido como uma proclamação niilista de que "o ente é sem importância", de que nada tem valor (a cultura, a arte, a ciência, a dignidade do homem, Deus ...), mas, pondera Heidegger, significa "levar para diante do pensar a clareira da verdade do ser contra a subjetivação do ente em simples objeto"21.

Nesse sentido, sabemos que a ontologia e a ética, como disciplinas, trazem a "marca registrada" do tradicional modo metafísico de pensar: aquele que sistematiza, que representa, que dá um "estatuto científico" ao "objeto" de estudo de cada uma delas. No entanto, se

16 Id. ibid. p. 348.

17 Cf. FERRY, L.; RENAULT, A. La Question de l'Éthique après Heidegger. In: Système et Critique: Essais sur la critique de la raison dans la philosophie contemporaine. 2. ed. Bruxelles: Ousia, 1992. p. 77 e 78.

18 Cf. HEIDEGGER, M. Sobre o Humanismo. p. 365.

19 Cf. FERRY, L.- RENAULT, A. op. cit. p. 77.

20 HEIDEGGER, M. Sobre o Humanismo. p. 365.

21 Id. ibid. p. 365. 
são pensadas as noções do que é a metafísica e do que é a ética fora dos moldes pré-estabelecidos pela tradição, isto é, se são "pensadas originariamente", como Heidegger sugere, acreditamos ser possível estabelecer uma vinculação inevitável entre o modo de pensar a ética e o modo de pensar a questão do ser. Nosso propósito é o de tentar compreender em que sentido e peso fundamentais essa questão está configurada em Heidegger.

\subsection{DO ESQUECIMENTO DO SER A UMA ÉTICA ORIGINÁRIA}

Heidegger inicia o primeiro capítulo de Ser e tempo ${ }^{22}$ (Sein und Zeit, 1927) com uma "denúncia": Esquecemos de perguntar "o que é o ser" e, além disso, esquecemos esse esquecimento - o que torna a denúncia ainda mais séria. Como compreender esse duplo esquecimento?

A resposta não é simples. Com ela está implicada toda a tradição filosófica do Ocidente que, com os percalços de uma compreensão estreita e confusa da idéia de ser, teria simplesmente abandonado, pensa Heidegger, a questão primordial: a do sentido do ser.

Segundo ele, não obstante as pesquisas empreendidas por Platão e Aristóteles, a pergunta pelo ser tornara-se desnecessária. Na verdade, todo o pensamento posterior aceitara sem muita criticidade as formulações da ontologia antiga, criando-se daí alguns dogmas que orientaram, de maneira quase imperceptível, toda a tradição filosófica, tornando algumas dessas formulações mais importantes que outras. O sentido do ser não precisava ser investigado.

Paradoxalmente, a metafísica, a ciência mais elevada, a ciência do ser enquanto ser, teria deixado de lado o próprio ser ${ }^{23}$. Nesse ponto,

22 Em nossa pesquisa, utilizaremos a tradução francesa de Etre et Temps (1927). Traduit de l'allemand par François Vezin. Paris: Gallimard, 1999, cotejada com a tradução brasileira de Márcia de Sá Cavalcante. Petrópolis: Vozes, 1997, Parte I (da 6 edição) e Parte II (5\{ edição). A tradução, desta e também das demais obras em francês, é de nossa inteira responsabilidade.

23 A fim de compreendermos a crítica heideggeriana à metafísica, convém começarmos por entender as distorções impostas pela tradução dos termos 
Étienne Gilson - um dos principais intérpretes do tomismo em tempos mais recentes, portanto, em uma perspectiva filosófica absolutamente distinta da de Heidegger -, aproxima-se do pensamento heideggeriano ao declarar: "Tudo se passa como se a história da metafísica fosse a de uma ciência que se engana continuamente de objeto" ${ }^{24}$. Ao

que compõem a palavra "meta-física". A palavra grega physis (física) foi, com o tempo, traduzida como "natureza", portanto, como coisa, ente; e meta passou a ser captação do que há de suprassensível. Todavia, o significado originário de physis é muito mais do que natura, (que propriamente quer dizer, "nascer", "nascimento"), perdendo-se aí toda a força filosófica dessa palavra que, originariamente, "evoca o que sai ou brota de dentro de si mesmo (por exemplo, o brotar de uma rosa), o desabrochar, que se abre, o que nesse despregar-se se manifesta e nele se retém e permanece; em síntese, o vigor dominante (Walten) daquilo que brota e permanece". (HEIDEGGER, M. Introdução à Metafísica (1935). Apresentação e tradução de Emmanuel Carneiro Leão. 3. ed. Rio de Janeiro: Tempo Brasileiro, 1987. p. 44). Mas, esse vigor, que brota e permanece, foi e é ainda hoje entendido em sua significação posterior, ou seja, como "natureza" ou fenômenos a ela relacionados (nascer do sol ou da lua, movimento dos corpos celestes, crescimento das plantas, nascimento dos animais e dos homens etc.), desvirtuando, dessa forma, o seu sentido originário que Heidegger faz questão de lembrar: "A physis é o Ser mesmo em virtude do qual o ente se torna e permanece observável (...) significa o vigor reinante, que brota, e o perdurar, regido e impregnado por ele (...) Physis é o surgir (Ent-stehen), o extrair-se a si mesmo do escondido e assim conservar-se". (HEIDEGGER, M. Introdução à Metafísica. p. 45). Foi assim que a metafísica, omitindo esse sentido original da physis, ficou presa à representação, à essência das coisas esquecendo-se de perguntar sobre o ser como tal. (Sobre os desdobramentos da tradução de physis por "natureza", veja-se também: FOLTZ, Bruce V. Habitar a Terra. Heidegger: Ética Ambiental e a Metafísica da Natureza. Lisboa: Instituto Piaget, 2000. p. 155-158).

24 GILSON, Étienne. L'Être et L'Essence. Paris: Vrin, 2000. p. 316. Convém reiterar que essa afirmação está vinculada a pressupostos completamente opostos aos do autor de Ser e tempo, visto que o acento é posto no "entendimento" que continuamente se engana de objeto e não, como faz Heidegger, no "ser" esquecido pela metafísica; portanto, o que está em jogo em Gilson é a relação sujeito-objeto. Sobre isso, recomenda-se a obra citada do próprio Gilson e ainda BORNHEIM, Gerd A. Metafísica e Finitude. Porto Alegre: Movimento, 1972. p. 123-132. 
tentar responder a pergunta que ela mesma formulou, responde de tal maneira que a questão fundamental é esquecida. Assim, a pergunta permanece em aberto: O que é o ser? ${ }^{25}$.

Embora Heidegger também não ofereça resposta à pergunta pelo ser, podemos certamente afirmar que foi o pensador que mais se preocupou com o ser, que mais tentou pensá-lo ou, como constata Gerd Bornheim, que menos o evitou ${ }^{26}$.

Em Ser e tempo, já nas primeiras páginas, nosso filósofo expõe brevemente, ao falar da necessidade de uma repetição da questão do ser, as razões que deram origem às afirmações dogmáticas que se perpetuaram, nutrindo a omissão de um questionamento do $\operatorname{ser}^{27}$ : A - O ser é o conceito mais universal e vazio; B - O conceito de ser é indefinivel; $\mathrm{C}-O$ ser é um conceito evidente.

Ao discutir esses dogmas, Heidegger tenta "limpar o caminho" que impede o acesso à pergunta privilegiada pelo sentido do ser. $\mathrm{O}$ primeiro passo é fazer "desabar", uma a uma, as idéias preconcebidas;

25 Como nos mostra Gilson, o que se vê com mais freqüência no latim de São Tomás de Aquino é a palavra ens. O termo, segundo Gilson, não existe no latim clássico. Talvez, completa ele, isto explique porque os Romanos não deixaram, à época clássica, uma metafísica como legado, pois sem o ser não há nenhuma ontologia, nenhuma metafísica. Traduzir São Tomás sem ter em conta a diferença de sentido entre ens e esse, significa levar completamente à ruina a ontologia tomista. Como exemplo, Gilson apresenta a afirmação de São Tomás: "Primo in intellectu cadit ens". Se traduzirmos por: "o ser é o primeiro conhecido", estaremos falseando sua filosofia. É como se o Doutor Angélico houvesse dito: "primo in intellectu cadit esse". Para ele, o ente é o primeiro conhecido e não o ser. (Cf. GILSON, Étienne. op. cit. p. 381 e 382). Volta-se então à pergunta: o que é o ser? O que é o ente?

26 Cf. BORNHEIM, G. op. cit. p. 124 e 125.

27 A compreensão da referência heideggeriana à tradição torna-se indispensável para um maior entendimento da questão do próprio significado do ser. Contudo, não pretenderemos aprofundar o estudo do conceito de ser posto pela ontologia antiga. Também não discutiremos as influências que Heidegger sofreu dos escolásticos, de Descartes, Kant ou Husserl, pois extrapolaríamos os limites de nosso trabalho. Situaremos as questões na medida necessária para a compreensão da questão por ele lançada: a do esquecimento do sentido do ser. 
"sacudir a poeira" e "remover os entulhos" de uma tradição "enrugada", "petrificada", mostrando que a questão do ser não está tão suficientemente transparente como se pensava ${ }^{28}$. Entregue à omissão de um tal questionamento, a metafísica situa o ser no lugar do ente, $e$ vice-versa este no lugar daquele; ambos acossados numa estranha e não pensada confusão ${ }^{29}$.

Passemos às suas ponderações:

A - Considerar o ser como o conceito mais universal, como noção vazia, significa que explicações ulteriores são desnecessárias. No entanto, Heidegger defende que o conceito de ser está longe de ser claro, já dado; mas, antes, é o mais obscuro. Isto porque "o 'ser' não circunscreve a região mais elevada do ente, pois este último se articula conceitualmente em gênero e espécie"30. Assim, a universalidade do ser, segundo Heidegger, como também concebia Aristóteles, não pode estar atrelada ao gênero ${ }^{31}$. Os medievais também entendiam que o conceito de "ser" "transcende" toda universalidade genérica. O que significa dizer que ele ultrapassa e se situa acima da multiplicidade dos entes. Esse é um dos motivos pelo qual o "ser" não foi questionado.

28 Cf. HEIDEGGER, M. Être et Temps. p. 48.

29 Cf. HEIDEGGER, M. Sobre o Humanismo. p. 360.

30 HEIDEGGER, M. Etre et Temps. p. 26.

31 Temos em Aristóteles: "Não é possível que o Uno ou o Ser seja um gênero dos seres". Mais adiante: "Se se põe o Ser e o Uno como gêneros, as diferenças participarão necessariamente do Ser e do Uno, embora que, na verdade, nenhuma diferença participe de seu gênero; por essa razão, não parece que o Ser e o Uno devam ser postos como gêneros, nem como princípios". (ARISTOTE, op. cit. livre B, 3, 998 b, 22 e t. 2, livre K, 1, 1059 b, 31, respectivamente). Vejamos o raciocínio de Aristóteles: se o ser fosse gênero teria diferenças específicas e essas diferenças participariam do ser porque elas, como todas as coisas, são seres e, dessa maneira, no caso do ser, o gênero seria atribuído às diferenças. Ora, isso é impossível. Se o racional (diferença específica da espécie homem) fosse animal (gênero), a diferença específica tornar-se-ia sujeito tendo o gênero como atributo quando ela é apenas uma qualidade. Nesse caso, seria supérfluo definir o homem como animal racional, uma vez que a racionalidade já implicaria a animalidade. Cf. ARISTOTE, Métaphysique. t. 2, nota n. 3 de Tricot, p. 103 e AUBENQUE, P. op. cit. p. 229. 
Para Heidegger, porém, é justamente por isso que o ser precisa ser repensado.

B - Do caráter da absoluta universalidade decorre um outro: a indefinibilidade do ser. Novamente a questão: a lógica tradicional advoga que para se definir algo é preciso acrescentar ao gênero próximo a diferença específica. Ora, o ser, como acabamos de dizer, não tem gênero nem diferença específica, não podendo, portanto, ser definido; fazer isto, mostra-nos Heidegger, seria tratar o ser como um ente, seria como afirmar: "o ser é ..." (das Sein ist) e não se pode dizer o que ele é, como alguma coisa que "existe", como um ente que é causa ou que é efeito. Entretanto, tal impossibilidade não impede que se coloque a necessidade de investigar o que o ser significa; muito pelo contrário, é por não poder responder a "o que é o ser" que surge a imperiosa urgência de se "saber sobre" ele.

C - A terceira concepção dogmática que favorece o esquecimento do ser consiste em afirmar que, sendo esse conceito evidente por si, é inútil interrogar sobre ele. Seria como dizer o já compreensível: "o céu é azul" ou "eu sou feliz", como Heidegger exemplifica. Trata-se de algo que prescinde de qualquer explicação. Diz ele: "Mas essa inteligibilidade corrente não demonstra outra coisa senão a ininteligibilidade. Faz ver que toda atitude e todo ser, em relação ao ente como ente, encerra a priori um enigma"32.

Concluir, portanto, que o conceito de ser dispensa maiores investigações por constituir-se como o mais geral dos conceitos, por não ser passível de definição e por parecer evidente por si mesmo, seria, pensa Heidegger, algo apressado demais: "Que vivemos cada vez mais em certo entendimento do ser e que ao mesmo tempo o sentido de ser permanece envolto em obscuridade é o que prova a necessidade em princípio de repetir a questão do sentido de 'ser"’33.

Nas palavras de Marlène Zarader, "O projeto de Heidegger foi, pois, orientado desde o nascimento para a elucidação retrospectiva de um acontecimento sempre-já advindo, subitamente aberto e constantemente proferido: o ser" ${ }^{\prime 4}$. Toda a sua obra traduz o esforço de

32 HEIDEGGER, M. Etre et Temps. p. 27.

33 HEIDEGGER, M. Etre et Temps. p. 27.

34 ZARADER, Marlène. Heidegger e as Palavras de Origem. Trad. João Duarte. Lisboa: Piaget, 1998. p. 281. 
esclarecer e pensar com propriedade o que já foi dito e no entanto permaneceu impensado na questão sobre o ser.

Veremos agora, no essencial, o que está em jogo no questionamento do ser nos períodos caracterizados como a primeira e a segunda fase do pensamento heideggeriano. Mas o faremos apenas à guisa de uma apresentação ou, digamos, de uma "sondagem" inicial do que chamaremos de "ética" nos dois momentos de sua obra para, então, no terceiro capítulo concentrar nosso estudo na análise de uma possível ética no Primeiro Heidegger, mais precisamente em Ser e tempo.

\subsubsection{A pergunta pelo ser no Primeiro Heidegger}

Em Ser e tempo, Heidegger expõe a necessidade de repor a problemática do ser ou, de outro modo, expressa uma primeira tentativa de elucidar esse já-sempre-aberto da questão do ser, partindo de sua proposta de "desconstrução" ou "superação" dos conceitos basilares da metafísica, conceitos que a tornaram "insensível" quanto à sua própria essência. No entanto, chama-nos a atenção: "Quando se falar assim, no desenvolvimento da verdade do ser, de uma superação da metafísica, isto então significa: Pensar no próprio ser"35. O Filósofo quer com isto dizer que sua proposta não é rejeitar ou destruir a fi$\operatorname{los}_{\mathrm{i} i a^{36}}$, como assim muitos entenderam. Ele não pretende "restaurar"

35 HEIDEGGER, M. na sua Introdução de 1949 a Que é Metafísica? (1929). Trad. e notas de Ernildo Stein. São Paulo: Abril Cultural, 1973. (Coleção Os Pensadores). p. 254.

36 Heidegger não se preocupa em distinguir filosofia e metafísica; esses termos são lidos por ele como sinônimos, como uma forma de pensar o ser. Nesse caso, "superação da metafísica", entenda-se também, "superação da filosofia". Num escrito que faz parte da segunda fase de seu pensamento intitulado O Fim da Filosofia e a Tarefa do Pensamento (1964), Heidegger fala do "fim" como "acabamento da metafísica" ou "acabamento da filosofia". Entretanto, do mesmo modo que "superação" não traduz "destruição", aqui também "fim" ou "acabamento" não significa "processo que se encerra" ou "ruína", muito menos quer dizer "suprema perfeição" supostamente já alcançada pela Filosofia. A palavra "fim" (Ende) utilizada aqui por nosso autor, tem o mesmo sentido da palavra "lugar" (Out). Diz ele: "O fim da Filosofia é o lugar, é aquilo em que se reúne o todo de 
o passado da metafísica, mas tentar fazê-la retomar o seu próprio fundamento, que não é outro senão pensar o ser enquanto ser, pensar o ser a partir de um âmbito em que o mostre em seu desvelamento, isto é, em seu Sentido ou Verdade ${ }^{37}$. Assim, afirma Heidegger:

Um pensamento que pensa a verdade do ser não se contenta certamente mais com a metafísica; um tal pensamento não pensa contra a metafísica (...). A metafísica permanece a primeira instância da filosofia. Não alcança, porém, a primeira instância do pensamento. No pensamento da verdade do ser a metafísica está superada ${ }^{38}$.

A "desconstrução" da tradição metafísica à época de Ser e tempo (1927), que representa a "primeira fase" (até meados de 1930) do pensamento do autor, faz-se, pois, em termos de retorno às "fontes", às experiências originais, lá, num espaço antecipador onde as coisas podem ser compreendidas, como ressalta Loparic, numa atitude prémetafísica, pré-teórica, ante-objetiva, no interior do tempo do acontecer do ser-aí $i^{39}$. Diríamos: muito antes de o perguntar metafísico se transformar no que ele se transformou: no modelo de pergunta

sua história, em sua extrema possibilidade. Fim como acabamento quer dizer esta reunião". É considerando exatamente essa "reunião", esse "todo" da História da Filosofia, desde o início com a metafísica, ao final, com a constituição e autonomia das Ciências, que Heidegger, nesse texto, vai dar ao pensamento uma tarefa fundamental: repensar a questão mesma da Filosofia. No fundo, trata-se de uma tentativa de radicalizar a tarefa de Ser e tempo; de fazer pensar o que já foi dito e nunca pensado, a saber, o ser em sua essência desveladora ou, de outro modo, o ser longe do poder representacional do ente. Cf. HEIDEGGER, M. O Fim da Filosofia e a Tarefa do Pensamento. Trad. e notas de Ernildo Stein. São Paulo: Abril Cultural, 1973. (Coleção Os Pensadores). p. 260.

37 Cf. HEIDEGGER, M. na sua Introdução (1949) a Que é Metafísica? (1929). p. 259.

38 HEIDEGGER, M. na sua Introdução (1949) a Que é Metafísica? (1929). p. 254. Sobre a destruição da história da ontologia, cf. ainda o parágrafo 6 de Etre et Temps. p. 45-53.

39 Cf. LOPARIC, Z. "Psicanálise: uma leitura heideggeriana". Revista Veritas. Porto Alegre. v. 43, n. I, mar. 1998. p. 25-41. 
técnico-científica, interessada exclusivamente pelo ente enquanto tal, pelo ente "palpável", presentável.

A questão do ser é reformulada, pois, em Ser e tempo, a partir de uma ontologia fundamental ${ }^{40}$ que vê na interpretação do tempo, tal como pensado pela metafísica, a chave para se compreender como o sentido do ser foi esquecido. Para ela, o ser vem ligado ao tempo, porém, o único tempo possível é o "presente" ${ }^{41}$. Ernildo Stein resume

40 Em Ser e tempo, Heidegger explica que o termo "ontologia" é usado em suas investigações em sentido formalmente amplo, completamente diferente do que comumente é pensado, isto é, como uma dada disciplina filosófica entre outras. (Cf. Être et Temps, p. 53). Na sua Introdução (1949) a Que é Metafísica? (1929), Heidegger comenta o quanto de "embaraçoso" pode haver na expressão "ontologia fundamental" pois ela dá a entender que o pensamento que se propõe a pensar o ser (e não o ente), esteja ele mesmo na esteira de uma "ontologia", no sentido tradicional. Com "ontologia fundamental", Heidegger propõe "a passagem da metafísica para dentro do pensamento do ser", isto é, o retorno ao fundamento da metafísica. Contudo, o peso da tradicional representação permanece, em todo caso, bastante vivo. (Cf. op. cit. p. 260). Em Introdução à Metafísica (1935), Heidegger mostra que a palavra "ontologia" é tomada, tradicionalmente, como sistematização e doutrina do ente numa disciplina da Filosofia ou, entendida num sentido mais amplo, como a tentativa de traduzir o ser em linguagem partindo da questão: "o que há com o ser?" e não simplesmente "o que é o ente?". Para ele, essa última designação não vingou na mentalidade dos eruditos da filosofia acadêmica e chega mesmo a desaconselhar o uso, no futuro, dos termos "ontologia" e "ontológico". Declara: "Modos de investigação, separados entre si por todo um mundo, como só agora se constata com maior clareza, também não devem levar o mesmo nome". (Cf. op. cit. p. 67 e 68).

41 A determinação grega do ser como ousia contém a significação temporal de "presentidade": o ser do ente é compreendido como "entidade", portanto, como o que está disponível, "constantemente presente". Cf. DASTUR, Françoise. Heidegger et la Question du Temps. 3. ed. Paris: PUF, 1999. p. 28-38. Recomenda-se, sobretudo, a Segunda Parte, mais precisamente o parágrafo 19 de HEIDEGGER, M. Los Problemas Fundamentales de la Fenomenología (1927). Traducción y prólogo de Juan José García Norro. Madrid: Editorial Trotta, 2000. Nesta seção, o autor trata do conceito tradicional do tempo em Aristóteles. Cf. ainda HEIDEGGER, M. De l'essence de la liberté humaine (1930). Traduit de l'allemand par E. Martineau. Paris: Gallimard, 1996. No Capítulo II da Primeira Parte, 
do seguinte modo o comportamento circular do pensamento grego: "o ser é pensado a partir do tempo, e por sua vez o tempo é pensado a partir do tempo, e por sua vez o tempo é pensado como ser"42. Mas, na tradição metafísica, o tempo é pensado como tempo físico, e é este tempo físico que determina o pensamento do ser. Para Heidegger, argumenta Stein, deveria acontecer justamente o contrário: o tempo físico, que é um ente, é que teria que ser pensado a partir do ser. Na verdade, "Ser e tempo determinam-se mutuamente (...)"43.

Foi a concepção grega fisicista do tempo, ou de outro modo, a dificuldade de se pensar o tempo sem naturalizá-lo que impediu a compreensão adequada da relação entre ser e tempo. Daí germinou os consequentes atropelos dos quais falamos e ainda falaremos em relação à questão do ser. O tempo tomado como "presença constante" originou a concepção fisicista de eternidade, e assim, "sendo a eternidade um presente, sem passado nem futuro, o modelo de todo o ser será o ser eterno"; moldado segundo tal forma, o ente é sempre "a cópia imperfeita do ser que é eterno presente, presença constante" ${ }^{44}$. Isto explica porque o ente é sempre entendido metafisicamente em seu ser como "vigência"45; explica também porque o ser do ente é tido sempre "representado", "objetivado", "evidenciado". Trata-se de uma leitura do tempo orientada, decididamente, pelo "mundo", pela "natureza" em seu sentido mais amplo ${ }^{46}$, e aqui, importa a história factual, os fatos historiográficos fornecidos pelo tempo ôntico. Por esta razão, torna-se, então, para a metafísica tradicional, descabida e inútil a necessidade do retorno às "fontes" onde estão as experiências originárias em que foram obtidas as primeiras determinações do $s e r^{47}$. É uma compreensão vulgar do tempo, ontologicamente ingê-

Heidegger tece considerações detalhadas da plurivocidade da palavra ousia.

42 STEIN, Ernildo. Melancolia. Ensaios sobre a finitude no pensamento ocidental. Porto Alegre: Movimento, 1976. p. 67.

43 HEIDEGGER, M. Tempo e Ser (1962). Trad. e notas de Ernildo Stein. São Paulo: Abril Cultural, 1973. (Coleção Os Pensadores). p. 456.

44 STEIN, Ernildo. op. cit. p. 66.

45 Cf. HEIDEGGER, M. Etre et Temps. p. 51.

46 HEIDEGGER, M. Etre et Temps. p. 51.

${ }^{47}$ Id. ibid. p. 47. 
nua, no dizer de Heidegger, em que só se tem em vista as regiões e os modos de ser "temporal" (processos naturais e os acontecimentos da história) ou "não temporal" (as relações numéricas e espaciais) dos entes. Importa o ente "sendo e estando no tempo"48. Importa sempre o "agora" ou o "não-mais-agora" (passado) ou o "ainda-não-agora"49 (futuro). Assim, coloca Heidegger, a ontologia antiga se baseou numa interpretação do ser que

se desenvolve (...) na ausência de todo saber explícito referente ao fio condutor que aí está em função, sem conhecer, sem mesmo compreender a função ontológica do tempo que lhe é subjacente, sem um olhar para sondar a possibilidade dessa função. Ao contrário: o próprio tempo é tomado como um ente entre os outros entes e esforça-se por apreender sua estrutura de ser, tendo por horizonte a compreensão do ser que é implicitamente e ingenuamente orientada sobre si ${ }^{50}$.

Com sua ontologia fundamental, Heidegger "desconstrói” a noção tradicional do tempo e do ser como presentidade, recolocando a questão do ser de modo inteiramente inovador: a partir do tempo, sim, no entanto, não mais a partir do tempo físico, mas da temporalidade humana. Como destaca Stein: "o tempo é ligado ao homem, o homem ligado ao ser, e assim o ser ligado ao tempo" ${ }^{1}$. Heidegger mostra que Aristóteles já pressentira o tempo (mesmo concebido fisicamente) como relacionado à "alma" ou ao "espírito"52, mas essa relação nunca fora adequadamente explorada.

48 Id. ibid. 43 e 44.

49 Cf. HEIDEGGER, M. Introdução à Metafísica. p. 227 e ainda: HEIDEGGER, M. De la Compréhesion du Temps dans la Phénoménologie et dans la pensée de la Question de l'Être. In: Quetions III et IV. Traduit de l'allemand par Jean Beaufret et alii. Paris: Gallimard, 2000. p. 353.

50 HEIDEGGER, M. Etre et Temps. p. 52. (Grifos nossos).

51 STEIN, E. op. cit. p. 67.

52 Cf. HEIDEGGER, M. Etre et Temps. p. 495. Cf. também ARISTOTE, Physique. Traduction et présentation par Pierre Pellegrin. Paris: Flammarion, 2000. Livre IV, 14, 223 a, 25. 
Tal é o empreendimento heideggeriano: através da análise da existência de um ente privilegiado, o Dasein humano, o ser-ai ${ }^{53}$, mostrar como o tempo e o ser são originariamente ligados. Com a sua analítica existencial, ele vai na direção de mostrar que o tempo não é de modo algum, como assinala Michel Haar, "uma propriedade das coisas, um meio no qual elas se desenvolvem" ${ }^{54}$, se produzem ou, como Henri Birault, "a condição sensível universal de todos os fenômenos possíveis (...)" "55. O tempo é, antes de tudo, a constituição fundamental de um ente que não está simplesmente no tempo, mas é tempo, é o seu tempo ${ }^{56}$. Assim, tendo a temporalidade como modo de ser fundamental, o Dasein é sempre as suas possibilidades ontológicas; dito de outra maneira, a existência do ser-aí é compreendida a partir do seu poder-ser ${ }^{57}$. Ele se compreende em seu ser, isto é, "sendo", podendo escolher ser de maneira própria ou imprópria - é um ente que se "relaciona" com seu próprio ser. Neste caso, "a questão do ser revela e é revelada pelo ethos do Dasein"58.

53 Em nosso trabalho aparecerá indistintamente a palavra Dasein e a expressão ser-ai usada por alguns estudiosos, como sua tradução. Outras expressões como estar-aí, pre-sença, eis-ai-ser (há quem use esta expressão!) ficarão restritas às citações textuais. A expressão Dasein, "ser-aî", que designa o ente que nós mesmos somos, não significa o mesmo que "ser humano", mas o "lugar" de desvelamento do ser. E é por essa razão que Heidegger também evita, e não é por "capricho terminológico", o uso de termos tais como "homem", "sujeito", "alma", "consciência", "ego", "espírito" e mesmo "pessoa" e "vida" (a estes, Derrida inclui o "inconsciente"), visto que arraigados à posição cartesiana de subjectum, apagam ou, pelo menos, não suscitam a possibilidade de qualquer pergunta pelo ser do ser-aí. (Cf. o parágrafo 10 de Ser e tempo e ainda recomenda-se DERRIDA, Jacques. Heidegger et la Question: De l'esprit et autres essais. Paris: Flammarion, 1990. p. 3). Quanto à significação de Dasein, conferir a nota n. 166 do segundo capítulo.

54 HAAR, Michel. La Fracture de l'Histoire. Douze essais sur Heidegger. Grenoble: Jérôme Millon, 1994. p. 73.

55 BIRAULT, Henri. Heidegger et l'Expérience de la Pensée. Paris: Gallimard, 1986. p. 536.

56 HEIDEGGER, M. De l'essence de la liberté humaine. p. 129.

${ }^{57}$ Heidegger chama a temporalidade originária do Dasein de "temporalidade eks-tática". A propósito, ver a nota n. 321 do terceiro capítulo.

58 HODGE, Joanna. Heidegger e a Ética. p. 48. 
Com isto, Heidegger mostra o fenômeno originário da temporalidade do Dasein. É o único ente que pode viver sua temporalidade: "propriamente", quando ele escolhe a si mesmo, quando antecipa o seu ser-para-a-morte e determina suas possibilidades de ser em vista dessa possibilidade irremediável, a possibilidade da impossibilidade; e, "impropriamente", quando escolhe a existência do tempo público, a estabilidade da opinião pública, o próprio-impessoal; o seu poder-ser é determinado pelo ser-como-todo-mundo, pelo tempo impróprio ${ }^{59}$. Segundo assinala Jean Grondin, Heidegger não explicita com maiores detalhes, concretamente, modalidades de existir "propriamente", sendo mais fácil de identificar as "modalidades impróprias". Sublinha ele:

No registro do tempo, isto significa que à angústia de um futuro autêntico [próprio], portanto mortal e finito, a existência inautêntica [imprópria] prefere a presença do "on", a presença eterna, a eternidade do mesmo que não conhece nem finitude, nem mortalidade (...). De acordo com o "on", o tempo não representa mais o índice do ter-que-ser-finito do Dasein, mas a série infinita, portanto, eterna, dos "agoras". 60

É no tempo primordial do Dasein, o tempo finito, que o ser "se faz" questão. Assim, o esquecimento do ser pela metafísica só pode ser genuinamente compreendido se ele é compreendido também no plano do esquecimento do tempo originário do Dasein $^{61}$. Como Heidegger afirma,

(...) toda questão metafísica somente pode ser formulada de tal modo que aquele que interroga, enquanto tal, esteja implicado na questão, isto é, seja problematizado. (...) a interrogação metafísica deve desenvolver-se na totalidade e na situação fundamental da existência que interroga ${ }^{62}$.

59 Cf. GRONDIN, Jean. "La persistance et les ressources éthiques de la finitude chez Heidegger". In: Revue de Métaphysique et de Morale.93e année, n. 3. Juil/sept. 1988. p. 384-386.

$60 \quad C f$. GRONDIN, J. op. cit. p. 386.

${ }^{61}$ HEIDEGGER, M. Etre et Temps. p. 387.

62 HEIDEGGER, M. Que é Metafísica. p. 233. 
Dessa forma, a ética que podemos ver sinalizada em Ser e tempo é aquela que convoca o ser-aí, marcado pelo intransponível caráter negativo que o constitui - o de ser-aí-no-mundo e ser-para-a-morte a se apropriar da sua condição de ente finito, a assumir o seu modo de ser mais próprio, o seu ter-que-ser (das Zu-sein-haben), à luz da possibilidade de não-mais-ser. Trata-se da ética do morar num mundo-projeto, implicado com o seu ter-que-ser, atento ao apelo "interior" da consciência que convida o ser-aí a cuidar de seu ser. Como formula Joanna Hodge,

A ética seria então o evento do Dasein, revelado como uma relação com o ser. É um evento que abre possibilidades em vez de uma ocorrência, que apresenta o que existe. Esse evento é o momento em que se revela a investigação ontológica como fundamentada em termos ônticos, no qual o Dasein pode dominarse dominando as suas próprias limitações ${ }^{63}$.

Retornaremos a essa questão, oportunamente, de modo mais atento e detalhado, no capítulo final deste trabalho, quando tomaremos o propósito de investigar uma ética plausível na analítica existencial, a partir dos modos possíveis de ser do ser-aí, os existenciais, e a sua estrutura fundamental de ser-no-mundo, aí, compreenderemos melhor o fenômeno da temporalidade originária, que não é outra coisa senão isto: a finitude do existir humano.

\subsubsection{A pergunta pelo ser no Segundo Heidegger}

A década de 1930 demarca o período caracterizado como a "segunda fase" do pensamento heideggeriano em que o Filósofo deixa de lado a idéia de tentar encontrar o fundamento esquecido da metafísica através de uma ontologia fundamental. Cada vez menos Heidegger falará de uma "superação" (Überwindung), substituindo-a por "apropriação" (Verwindung) da metafísica, no sentido de "penetrar nela, assumindo o destino, apropriar-se dela e, em certo sentido, liberá-la para isto que ela tem de mais próprio" ${ }^{64}$. A questão primordial a ser

63 HODGE, J. op. cit. p. 270. (Grifos nossos).

64 Segundo Grondin, a palavra Verwindung é intraduzível. Os comentadores de Heidegger, incluindo os alemães, sentem dificuldade em traduzir a 
pensada continua sendo a questão do ser, porém não mais sob o prisma do método fenomenológico ${ }^{65}$ que buscava o "sentido" do ser, mas a partir da pergunta pela Verdade (Wahrheit) ${ }^{66}$ em seu caráter historial ou Destinamental (Seinsgeschichtlich). O "filósofo do ser" explica:

Abandonando o termo sentido do ser pelo de verdade do ser, o pensamento proveniente de 'Sein und Zeit' insiste mais sobre a própria abertura do ser do que sobre a abertura do Dasein face à abertura do ser. Tal é a significação da viravolta (die Kehre), pela qual o pensamento se volta cada vez mais para o ser enquanto ser ${ }^{67}$.

expressão Verwindung utilizada por Heidegger que é tomada tanto por "apropriação" (Cf. HEIDEGGER, M. "Contribution à la question de l'être". In: Questions I et II. Traduit de l'alemand par Kostas Axelos, Jean Beaufret et alii. Paris: Gallimard,2001. p. 236) como por "aceitação-e-aprofundamento" (Cf. HEIDEGGER, M. "Dépassement de la Métaphhysique". In: Essais et Conférences. Traduit de l'alemand par André Préau et préfacé par Jean Beaufret. Paris: Gallimard, 1999. p. 80. Ver nesta mesma página o comentário da nota n. 3). Cf. também GRONDIN, J. Le Tournant dans la Pensée de Martin Heidegger. Paris: PUF, 1987. p. 105.

65 “(...) Pelo método fenomenológico se desvendou esta circularidade, que passa, por sua vez, a possibilitar uma verdadeira penetração na fenomenologia. A estrutura circular da interrogação heideggeriana leva-o ao que chamará de viravolta (Kehre). Na estrutura circular do ser-aí se revela que a análise do ser-aí pressupõe uma compreensão do ser; mas, uma compreensão do ser, supõe, quando quer ser explícita, uma analítica do ser-aí. A Kehre é um movimento pelo qual o Filósofo, uma vez realizada a mediação pela analítica, se volta para o ser e a partir dele analisa o homem. A estrutura circular do ser-aí, de início reduzida ao âmbito da analítica, se converte em movimento - na história de um pensamento - pelo qual este se volta para o ser. O caráter hermenêutico da fenomenologia toma então um sentido mais amplo e radical, determinando-se a dimensão hermenêutica não mais só a partir do homem, mas a partir do ser (...)". STEIN, E. A Questão do Método na Filosofia: um estudo do modelo heideggeriano. 3. ed. Porto Alegre: Movimento,1991. p. 111.

66 "Ultrapassar a metafísica, é livrá-la e remetê-la à sua própria verdade". HEIDEGGER, M. "Dépassement de la Métaphysique". In: Essais et conférences. p. 90.

67 HEIDEGGER, M. "Les Séminaires du Thour" (1966). In: Questions III et IV. Paris: Gallimard, 1976. p. 433 e 434. 
Com isso, Heidegger traz à luz a compreensão de um caráter negativo do ser ainda mais forte do que aquele em que permeava a estrutura do tempo finito do Dasein como ser-no-mundo. Trata-se do caráter negativo do ser como Aléthéia, como manifestação, em virtude do qual o desvelamento é sempre pensado como um não-velamento (Unverborgenheit). Nas palavras de Carlos Morujão, "O Ser é pensado como o que domina e se desvela - e o seu desvelamento é um modo do seu domínio, sendo o outro, o ocultamento, coessencial com o primeiro" $" 68$.

Nesse sentido, no Segundo Heidegger, a "destruição" da noção do tempo como presentidade é realizada a partir da tematização da diferença ontológica, agora, foco central de atenção do autor de Ser e tempo: "o caráter peculiar do ser graças ao qual o ser se oculta enquanto deixa aparecer os entes" ${ }^{69}$. É esta "experiência" de ocultaçãodesocultação, de doação-retração que revela o caráter temporal do ser, como Ereignis, como Acontecimento; revela a finitude do próprio ser. Aí dá-se a verdade do ser. E a tarefa imposta ao pensamento é pensá-la como o que há de mais digno de ser pensado.

Entre os estudiosos do pensamento heideggeriano há quem compartilhe da opinião de que esta tarefa continua, afinal, sendo a mesma que Heidegger vinha empreendendo desde os primeiros escritos: pensar o impensado pela metafísica, lá nas suas origens, onde reside o seu fundamento. Continua sendo um convite a abandonar o modo de pensar e agir representativamente (o homem como animal racional, a verdade como adequação, o ser como fundamento do ente, etc.), mas, agora, com uma diferença: Heidegger propõe uma "transformação do pensar" (Verwandlung des Denkens), um "passo para trás" (Schritt zurück), um "salto" (Sprung) que, ao mesmo tempo em que é a saída súbita dos esquemas representativos da metafísica é, paradoxalmente, a entrada nas suas origens, onde é possível pensar o ser como processo de manifestação, como "Acontecimento-apropriação"

68 MORUJÃO, Carlos. Verdade e liberdade em Martin Heidegger. Lisboa: Instituto Piaget, 2000. p. 127.

69 VATTIMO, G. As Aventuras da Diferença: o que significa pensar depois de Heidegger e Nietzsche. Tradução de José Eduardo Rodil. Lisboa: Edições 70, 1988. p. 87. 
(Ereignis), modo de pensar jamais experimentado pela metafísica; em que, perdidas as determinações (sobretudo a de sujeito-objeto) que a metafísica lhes imprime, homem e ser estão reciprocamente entregues a um "comum-pertencer"70.

Nessa segunda fase, a questão do ser é colocada, pois, em termos de sua verdade epocal ou historial. A metafísica é a história do ser" "narrada" em termos de um esquecimento primordial. Nessa perspectiva, para Heidegger, o esquecimento do ser não se deu por um "lapso" ou por um "erro" ao qual a civilização ocidental sucumbiu, como ele mesmo diz na sua carta Sobre o Humanismo ${ }^{72}$ (1947) onde retoma as posições fundamentais da obra monumental de 1927. O esquecimento, enfim, não deve ser entendido como o "pecado original" dos metafísicos, não se deu por uma simples negligência do pensamento, mas, para Heidegger, deve ser pensado como um acontecimento, pertence ao destino essencial da metafísica ${ }^{73}$. Dito de outra maneira, o esquecimento faz parte do modo como o ser se manifesta, concerne ao próprio ser, como a não-verdade pertence à

70 A propósito, Cf. HEIDEGGER, M. Identidade e Diferença (1957). Trad. e notas de Ernildo Stein. São Paulo: Abril Cultural, 1973. (Coleção Os Pensadores). p.381 e 383; Cf. HEIDEGGER, M. A Constituição Ontoteo-lógica da Metafísica. Trad. e notas de Ernildo Stein. São Paulo: Abril Cultural, 1973. (Coleção Os Pensadores). p. 390 e 391; e ainda BLANC, Mafalda Faria. O Fundamento em Heidegger: "Von wesen des Grundes" - "Der Satz vom Grund": Interpretação - Perspectivação. Lisboa: Instituto Piaget, 1998. p. 122 e 123.

71 Título dado por Heidegger ao capítulo VII de sua obra Nietzsche II.

72 Cf. HEIDEGGER, M. Sobre o Humanismo. p. 355.

73 Cf. HEIDEGGER, M. na Introdução acrescentada em 1949 à conferência O Que é Metafísica? (1929). p. 255. Convém esclarecer que Geshick (Destino) deriva-se de Schicken que significa "enviar", "mandar", "destinar", "transmitir"; portanto, para uma tradução fiel, o termo "Destino" deve ser tomado em seu sentido etimológico, ou seja, em sentido ativo, como o que destina e dá origem à História (Geschichte). Cf. a nota explicativa n. 13 de LEÃO, Emmanuel Carneiro In: HEIDEGGER. M. Introdução à Metafísica. p. 78. 
própria essência da verdade ${ }^{74}$. Por essa razão, assinala Vattimo, o ser é, como vimos, uma noção ao mesmo tempo óbvia e vaga ${ }^{75}$.

O "esquecimento", em síntese, faz parte do modo como nós nos comportamos em relação ao ser, como nós somos ou existimos em relação a ele ${ }^{76}$, como também faz parte do mostrar-se, do revelar-se do próprio ser. Esse esquecimento, pois, não é um esquecimento ôntocopsicológico qualquer, semelhante ao esquecimento de algum objeto que "tínhamos nas mãos" (a bolsa ou o cigarro, por exemplo); o esquecimento do ser acontece na medida em que o pensamos como presentidade, como ente, isto é, como algo disponível, algo que está à mão.

Para Heidegger, a prova mais patente do esquecimento do ser está no primado da vontade de potência, o último estágio da história da metafísica ${ }^{77}$, que constitui a atualização da metafísica em suas

74 Cf. HEIDEGGER, M. Sobre a Essência da Verdade (1930). Trad. e notas de Ernildo Stein. São Paulo: Abril Cultural, 1973. (Coleção Os Pensadores). p. 337.

75 Cf. VATTIMO, Gianni. Introduction à Heidegger. Traduit de l'italien par Jacques Rolland. Paris: Les Éditions du Cerf, 1985. p. 91.

76 “(...) não é simplesmente alguma coisa, diante da qual estamos, como algo estranho; alguma coisa que apenas pudéssemos constatar, como um dado, em sua presença objetiva. Trata-se de algo em que nos achamos. É um estado da nossa existência, embora não entendido, naturalmente, no sentido de uma qualidade, que pudéssemos apresentar psicologicamente. 'Estado' significa aqui toda a nossa constituição, a maneira como nós mesmos nos constituímos com referência ao ser". HEIDEGGER, M. Introdução à Metafísica. p. 75 e 76.

77 Nas diversas épocas da História da metafísica o ser do ente fora representado de variadas formas, como se o ser fosse uma qualidade ôntica geral em relação a cada ente: phýsis, lógos, hén, idéa, enérgeia, substancialidade, objetividade, vontade, vontade de poder, vontade de vontade (Cf. HEIDEGGER, M. A Constituição Onto-teo-lógica da Metafísica. p. 397). Cada uma dessas formas articula um caráter particular do ser enquanto tal, não sendo lidas como modos epocais de como o ser "se dá", é por isso que, em todos os casos, afirma o "filósofo do ser", a metafísica continua sempre "física", ou seja, a questão sobre o ser, como tal, investigada à luz da metafísica permanece uma simples repetição mecânica da questão sobre o ente, como tal (Cf. HEIDEGGER, M. Introdução à Metafísica. p. 48), por conseguinte, persiste o esquecimento do ser, persiste também o esquecimento da essência da metafísica. 
formas fundamentais de manifestação - o cálculo e a organização de todas as coisas ${ }^{78}$ - em que as relações técnicas surgem como uma "projeção do ser, revelando o que existe no mundo de uma maneira particular e sistemática"79. Assim, pensa Heidegger, a técnica, na forma de metafísica atualizada, "atualiza" o esquecimento da diferença ontológica, na medida em que dilui a distância que há entre "o que existe e como é que existe dessa maneira" ao dissipar a possibilidade da pergunta "por que as coisas são assim e não de outro modo?" técnica encontra, pois, a sua legitimação mais extrema e suprema no princípio metafísico do fundamento, objeto de nosso segundo capítulo, que, como principium magnum, grande et nobilissimum ${ }^{81}$, vem computar, representar, calcular, validar e assegurar a existência de todas as coisas $^{82}$.

Todavia, é preciso que se diga, e num de seus textos mais famosos dos Ensaios e Conferências (1954) Heidegger deixa claro, que a técnica é também um modo do desvelamento do ser, ela "desvela seu ser (west) na região onde o desvelamento e a não-ocultação, onde Aléthéia, onde a verdade tem lugar" ${ }^{83}$. Ele já tinha dito isto antes, em Sobre o Humanismo (1947): "A técnica é, em sua essência, um destino ontológico-historial da verdade do ser, que reside no esqueci-

78 Cf. HEIDEGGER, M. Dépassement de la Métaphysique. In: Essais et Conférences. p. 92.

79 HODGE, J. op. cit. p. 135. (Grifos nossos).

80 HODGE, J. op. cit. p. 55 e 56.

81 Cf. HEIDEGGER, M. Le Principe de Raison (1955-1956).Traduit de l'Allemand par André Préau et Préface de Jean Beaufret. Paris: Gallimard, 1999. p. 116.

82 "A perfeição da técnica não é outra coisa senão um eco do apelo exigindo a perfectio, isto é, a fundação completa sobre razões. Este apelo nos fala pela voz do principium reddendae rationis sufficientis (...) A técnica moderna tende para a maior perfeição possível. Esta perfeição consiste na calculabilidade dos objetos. A calculabilidade dos objetos pressupõe a validade universal do princípio de razão. Enfim a dominação, assim entendida, do princípio caracteriza o ser da época moderna, da idade técnica". HEIDEGGER, M. Le Principe de Raison. p. 255.

83 HEIDEGGER, M. La Question de la Technique. In: Essais et Conférences. p. 19. 
mento. (...) Enquanto uma forma de verdade, a técnica se funda na história da Metafísica" $"$.

O "perigo" mora justamente aí. A história da metafísica deságua, dada a sua dominação absoluta do ente, num tipo de verdade em que prevalece a objetividade, o arrazoamento (Gestell) ${ }^{85}$, isto é, a racionalidade técnica, o planejamento, a previsibilidade, a calculabilidade de tudo o que existe, inclusive da existência humana. Num escrito de 1957, intitulado Identidade e Diferença (Identität und Differenz), Heidegger afirma que "pela representação da totalidade do universo técnico reduz-se tudo ao homem e chega-se quando muito, a reivindicar uma ética para o mundo da técnica (...) Passa-se por alto o apelo do ser, que fala na essência da técnica" ${ }^{" 16}$.

$\mathrm{Na}$ época da metafísica atualizada, isto é, na época em que o ente se organizou de tal maneira que cada vez mais assumiu a roupagem da técnica, "a essência do homem se encontra cada vez minimizada e não pensada em sua origem" ${ }^{\text {" }}$. O homem se acha ameaçado em sua essência, massificado perante o domínio técnico do mundo, onde o agir é o agir planejado, nivelado por uma noção ética do iguali-

84 HEIDEGGER, M. Sobre o Humanismo. p. 361.

85 Ernildo Stein traduz a palavra Gestell, (em alemão significa "armação", "suporte", "estante", etc.) por "Arrazoamento". Também é traduzido pelos termos "com-posição" (o próprio Stein o fizera), "im-posição" (Vattimo), "armação" (Loparic) ou ainda por "com-posto". Stein explica que o termo Gestell provém do verbo stellen, que tem o sentido de "apontar o lugar, fixar, regular, provocar, exigir contas", e é usado por Heidegger "para definir aquele âmbito que se cria pelo confronto entre homem e técnica (...) na medida em que ambos se provocam, exigem contas um do outro, chamam-se à razão reciprocamente (...). Também exprime o império da razão que tudo invade pela técnica, que caracteriza uma época em que o homem busca as razões, os fundamentos de tudo, calculando a natureza, e em que a natureza provoca a razão do homem a explorá-la como um fundo de reserva sobre o qual dispõe". STEIN, E. em sua nota n. 4, In: HEIDEGGER, M. Identidade e Diferença. p. 382. Ver ainda HEIDEGGER, M. La Question de la Technique. In: Essais et Conférence. p. 28ss; bem como: HEIDEGGER, M. La fin de la philosophie et le tournant. In: Questions III et IV. p. 309ss.

86 HEIDEGGER, M. Identidade e Diferença. p. 382.

87 HEIDEGGER, M. Sobre o Humanismo. p. 352. 
tarismo, do "a gente" que faz de "cada um", "ninguém" e de "ninguém", "todo mundo" (itálicos nossos de expressões de Loparic). Segundo ressalta Loparic,

A defesa contra o perigo da técnica, o perigo da presença, consiste, (...) no pensar a não-presença. A salvação vem do não-presentável. Afunda, assim, à base da cultura ocidental, a clara e direta objetividade da natureza, que tanto fascinou os gregos, assim como todos os seus sucedâneos ${ }^{88}$.

Pode-se dizer, neste sentido, que para evitar o perigo da técnica é urgentemente necessária uma recuperação da ética que só é possível com a recuperação da questão do ser. Como Heidegger assinala: “(...) parece que a metafísica, sem o seu conhecimento, está condenada a ser, pela maneira como pensa o ente, a barreira que impede que o homem atinja a originária relação do ser com o ser humano"89.

Assim, a ética que os escritos mais recentes de Heidegger ${ }^{90}$ dá a pensar, refere-se a uma ética Destinamental ou da Correspondência, que exigirá do ser humano um ter-que-corresponder ao chamamento do ser, à verdade do ser; exigirá um reaprender a morar na terra, resguardando-se, preservando-se do perigo supremo ao qual está subjugado no mundo da técnica: o de, na medida em que os entes se apresentam ao homem como o "armazenamento" do que é simplesmente "calculável", "negociável", "presentável", o próprio homem corre o risco de sujeitar-se à mera função objetiva das relações técnicas. Como Heidegger sublinha, tudo se passa numa total ausência de meditação; ele chega a narrar uma "incapacidade organizada", impenetrável, de aceder a uma relação com o que merece ser interrogado ${ }^{91}$. Para Heidegger:

88 LOPARIC, Z. O Fim da Metafísica em Carnap e Heidegger. In: DE BONI, Luis A. (Org.). Finitude e Transcendência. Festschrift em Homenagem a Ernildo J. Stein. Petrópolis: Vozes, 1996. p. 801.

89 HEIDEGGER, M. na sua Introdução de 1949 a Que é Metafísica? (1929). p. 255.

90 Cf. HEIDEGGER, M. especialmente Sobre o Humanismo, O Princípio de Fundamento, os textos sobre a técnica e a obra de arte, dentre outros.

91 Cf. HEIDEGGER, M. Dépassement de la Métaphysique. In: Essais et Conférences. p. 100. 
O técnico, representado no sentido mais amplo e segundo suas múltiplas manifestações, é considerado como o plano que o homem projeta; este plano finalmente o força a decidir entre tornar-se escravo de seu plano ou permanecer senhor dele ${ }^{92}$.

Em síntese, tal é o seu "dever originário": corresponder, morar na verdade do ser. Para o Segundo Heidegger, "morar" não significa mais ser "projeto-lançado", "confrontar-se" com as possibilidades de ser-no-mundo e a possibilidade irremessível de não-mais-ser-no-mun$\mathrm{do}^{93}$. Morar significa "edificar" (bauen), não no sentido de "fazer instalações", "equipar", "produzir" artefactos que facilitem o "alojamento" do homem no mundo, mas no sentido originário de pensar e poetar $^{94}$. Para Heidegger o pensar e o poetar originários são o modo privilegiado de proximidade ao ser, porquanto são o modo privilegiado de "dizer" o ser. São, pois, diz Heidegger, o "fazer habitar" origi$n a l^{95}$, um meio de conservar-se do perigo das relações técnicas. Nas palavras de Bertrand Vergely, "O homem habita o mundo quando compreende que sua permanência mais segura neste mundo reside no pensamento" "96 na atitude poética.

Por ora, abandonemos a discussão como estáa ${ }^{97}$. Tudo isto foi dito, como já ficou esclarecido, a fim de proporcionar um panorama geral de como, nos dois momentos da obra heideggeriana, pode estar situada a questão do ser numa correspondência com uma ética possível. O nosso enfoque estará no Capítulo Terceiro, na análise da possibilidade de uma ética em Ser e tempo.

Enfim, com base em tudo o que vimos, poderíamos então perguntar: a questão do ser pode ser "recuperada" com a questão da

92 HEIDEGGER, M. Identidade e Diferença. p. 381.

93 Cf. LOPARIC, Z. Ética e Finitude. p. 76.

94 Cf. Id. ibid. p. 77.

95 Cf. HEIDEGGER, M. '...L' Homme Habite en Poète...' in: Essais et Conférences. p. 242.

96 VERGELY, Bertrand. Heidegger ou l'Exigence de la Pensée. Toulouse: Éditions Milan, 2001. p. 47. (Grifo nosso).

97 Para um estudo mais aprofundado sobre a ética encontrada no Segundo Heidegger, recomenda-se: LOPARIC, Z. Ética e Finitude, bem como: FOLTZ, Bruce V. op. cit. 
ética, ou a questão da ética pode ser "recuperada" com a questão do ser? ${ }^{98}$

Recordando uma passagem da carta Sobre o Humanismo (Über den Humanismus, 1947), arriscaríamos responder: as duas coisas. Quando Heidegger, aqui, fala a Beaufret da necessidade de se repensar a ética longe da dominância metafísica que reclama por princípios racionais fundantes da ação humana, que o essencial é pensar o ethos como "morada do homem", ele deixa entrever a possibilidade de uma nova ética. Uma ética como os gregos a viam: aquela que engloba a "existência como um todo" e não simplesmente o que concerne a ações "proibidas" ou "liberadas" 9 .

Bruce Foltz chama a atenção para essa noção irrestrita do ético em Heidegger: a etimologia da palavra ethos, antes de "costume" e "hábito", significava "um local costumeiro"; no plural ethea, significava "assentos, lugares, residência, primeiro dos animais, mas depois dos seres humanos". Segundo o autor, tal alargamento do sentido do ético não só para a humanidade, para o sensível, mas para o todo das entidades, salva a ética "da estreiteza do conceito moderno de ética como uma teoria da obrigação moral que apenas diz respeito a alguns tipos de ações questionáveis, e deixa o resto da existência humana a errar no domínio do arbitrário"100. Como afirma Sócrates, na República de Platão, “(...) é melhor examinar a questão, porquanto a discussão não é à deriva, mas sobre a regra de vida que devemos adoptar"101.

Se o "pensamento do ser" é o que mais importa, então as sementes da ética heideggeriana, nas duas fases que acabamos de esboçar, estariam, de alguma forma, ligadas a um morar na "abertura da

98 Segundo Hodge, "para evitar que esta lógica de atualização [da metafísica] se complete, é urgentemente necessária uma recuperação da ética". HODGE, J. op. cit. p. 25.

99 Cf. FOLTZ, Bruce V. Habitar a Terra: Heidegger, ética ambiental e a metafísica da natureza. Trad. Jorge Seixas e Sousa. Lisboa: Piaget, 2000. p. 202.

${ }^{100}$ FOLTZ, Bruce V. op. cit. p. 202.

${ }^{101}$ PLATÃO. A República. Introdução, tradução e notas de Maria Helena da Rocha Pereira. 9. ed. Lisboa: Fundação Calouste Gulbenkian, 2001. $352 \mathrm{~d}, 7-8$. 
transcendência", e a um morar na "abertura da acontecência", estariam ligadas à interpelação do ser, ao escutar "cuidadosamente" e "docilmente" o apelo que nos é dirigido. Neste caso, faz sentido as afirmações de Daniel Panis: "O pensamento da verdade do ser ou do sentido do ser pode então se chamar o pensamento ético original. Ou de çoutro modo, é já o ethos, a 'ética' em si, a habitação própria do homem"102.

Uma reposição da questão do ser e uma consequente ética originária seriam pensáveis quando o pensamento atingir a dimensão em que dirá o ser em sua verdade, em vez de explicá-lo como um ente a partir do ente ${ }^{103}$. Foi o modelo de explicação pelo ente que a metafísica ocidental adotou, como veremos a seguir.

\subsection{A QUESTÃO FUNDAMENTAL: UMA "META-ÉTICA"?}

Para mostrar a especificidade de sua investigação em relação à da metafísica tradicional, Heidegger diferencia duas questões: a questão condutora (Leitfrage) - "o que é o ente?" -, que é a da metafísica; e a questão fundamental (Grundfrage), a questão esquecida "qual o sentido do ser?"104 - que é a lançada por ele. De algum modo, essa diferenciação servirá para mostrar que Heidegger não se desvincula, ou como dissemos, não "destrói" a ontologia tradicional, pelo contrário, incorpora-a às suas próprias pesquisas ${ }^{105}$. E é por isso que

102 PANIS, Daniel. Il y a le "il y a": l'Énigme de Heidegger. Bruxelles: Ousia, 1993. p. 23 e 24.

103 Cf. HEIDEGGER, M. Sobre o Humanismo. p. 358.

${ }^{104}$ Cf. HEIDEGGER, M. Nietzsche I (1961) Traduit de l'allemand par Pierre Klossowski. Paris: Gallimard, 1998. p. 67 e 68. Veja-se também HEIDEGGER, M. Introdução à Metafísica. p. 68.

105 Assim é, por exemplo, a apropriação que Heidegger faz do esquema interrogativo da metafísica, ou mais precisamente, da pergunta pela essência em proveito de sua questão fundamental. Levada às últimas consequências, a pergunta metafísica pela entidade conduz Heidegger à pergunta pela compreensão pré-conceptual do ser. Visto por essa perspectiva, alguns estudiosos acreditam que não há uma ruptura e sim um progresso linear que vai da investigação metafísica sobre o ente, à investigação 
chama a pergunta central da metafísica de condutora (ou diretriz), por encontrar justamente nela o fio condutor, ou como ele próprio sublinha, a "fornalha ardente", a "lareira"106 que acalora a sua questão fundamental.

Contudo, há uma diferença capital intrincada nesses dois modos de perguntar - no da metafísica e no de Heidegger - e, a partir dessa diferença, Hodge tenta diagnosticar um modo ético e metafísico de investigação. Para ela, no pensamento heideggeriano há lugar para uma espécie de "meta-ética"107 na medida em que traz em si uma dimensão ética anterior à divisão entre a filosofia e a ética, anterior a qualquer sistema filosófico moral ou político. À interrogação metafísica, Hodge atribui um "quê" de investigação (mais ligado, diríamos, às origens ônticas) e, à interrogação ética, um "como" (mais ligado às pesquisas ontológica-transcendentais).

O interrogar essencial ou, como Hodge o chama, "meta-ético" não fecha nem as questões nem as respostas, como o faz o sistema metafísico da representidade. Não há um modo único de perguntar, como não há um modo único de responder. Isso implica, pois, uma profunda mudança de atitude teórico-prática que aponta, mesmo implicitamente, o vislumbre de uma nova ética consequente a ligada à um estar aberto a experiências essenciais que a linguagem metafísica é incapaz de pôr à prova à maneira de um objeto.

Quando se pergunta se "há algo", ou quando se "constata" que "há algo", o "há algo" quer dizer "sou tocado por algo", que "algo me é dado", que há uma "apropriação" de algo que não pode ser simplesmente "dável", objetivável, descrito nem psicologicamente nem fisicamente $^{108}$. O "há algo", diz Heidegger, provoca, antes, um espanto, um

heideggeriana sobre o ser. O que norteou inicialmente as pesquisas de Heidegger foi exatamente a intenção de fundamentar e clarificar o que se encontrava obstruído e confuso na filosofia tradicional. Cf. BLANC, Mafalda Faria. O Fundamento em Heidegger. p. 51.

106 Cf. HEIDEGGER, M. Introdução à Metafísica. p. 68.

107 Cf. HODGE, J. op. cit. p. 43.

${ }^{108}$ Cf. LOPARIC, Z. "Sobre a ética em Heidegger e Wittgenstein". Natureza Humana. Revista Internacional de Filosofia e Práticas Psicoterápicas. v. 2. Ano 1, 2000. p. 131. 
espanto intraduzível pelo dizer metafísico e científico ${ }^{109}$. Há somente de se perguntar: "por que o há ele-mesmo"? ${ }^{110}$, como nos faz refletir Daniel Panis:

(...) se admirar que há, não isto ou aquilo, mas o há ele mesmo, ser tocado pela questão: "mas por que então tudo isto que é - e

109 Nesse caso, como diria o primeiro Wittgenstein, a ética é este impulso de irmos contra os limites da linguagem - da linguagem científica pretendida por ele, aquela que busca "assegurar o controle efetivo de tudo o que está dito", de modo que "as coisas existem só num único sentido, o de serem objetos afiguráveis verbalmente". (Cf. LOPARIC, Z. op. cit. p. 132 e 138). Nesta perspectiva, só há uma linguagem humana possível, um único modo de dizer "o que há", aquele que afigura os fatos do mundo, os fatos naturais, averiguados pela lógica tradicional. "Para uma resposta que não se pode formular, afirma o Wittgenstein do Tractatus, tampouco se pode formular a questão". E continua: "O enigma não existe. Se uma questão se pode em geral levantar, a ela também se pode responder". (WITTGENSTEIN, Ludwig. Tractatus Logico-Philosophicus. Tradução, apresentação e estudo introdutório de Luiz Henrique Lopes dos Santos. Introdução de Bertrand Russell. 2. ed. São Paulo: Ed. da Universidade de São Paulo, 1994. Ver aforisma 6.5, p. 279). A ética, para Wittgenstein, "não é um estado de coisas subsistente e não tem nada a ver com fatos", portanto, está fora do espaço lógico, fora do mundo e não pode ser expressa pela linguagem. A respeito da ética em Wittgenstein e em Heidegger, é esclarecedor o mencionado artigo de LOPARIC, Z. "Sobre a ética em Heidegger e Wittgenstein" na já citada Revista Natureza Humana. p. 129-144.

110 Heidegger esclarece: “emprega-se o termo 'dá-se' [em alemão, es gibt e em francês, il y a] para, provisoriamente, evitar a expressão 'o ser é'; pois comumente diz-se o 'é’ das coisas que são. Estas nós as designamos de ente. Mas o ser justamente não 'é' 'o ente'. Se o 'é' vem dito, sem maior explicação, do ser, então o ser é representado com demasiada facilidade como um 'ente', ao modo do ente conhecido, que opera como causa e é operado como efeito. Contudo, já Parmênides afirma nos primórdios do pensamento: éstin gàr einai. 'É, a saber, o ser'. Nesta palavra esconde-se o mistério originário para todo pensar. Talvez o 'é' só possa ser dito, de maneira adequada, apenas do ser, de maneira tal que todo ente jamais propriamente 'é'. Mas como o pensamento deve atingir a dimensão em que dirá o ser em sua verdade, em vez de explicá-lo como um ente a partir do ente, deve ficar aberta a solicitude do pensar a questão, se e como o ser é". HEIDEGGER, M. Sobre o Humanismo. p. 358. 
não nada?", é correr o risco de colocar uma questão que não se chama mais questão pois privada de resposta, a questão no sentido mais próprio, aquela que não decorre de questão-resposta, mas que dura, que permanece questão. É a questão de um questionamento permanente ${ }^{111}$.

A metafísica, por sua vez, "procura apagar qualquer questão relacionada com as pré-condições para uma investigação"112 - aprioristicamente, ela é "causa-própria" de tudo o que investiga. O perguntar metafísico, mais tarde transformado em perguntar técnico-científico, é definido por abrigar em si a autonomia de decidir que questões devem ser formuladas, ou melhor, que questões "existem", quais são as "verdadeiras" - a saber, aquelas que podem ser objetivadas e que são solucionáveis.

Logo, na essência da metafísica se oculta um comprometimento ético, "uma vez que questiona o modo de vida no qual as interrogações filosóficas podem ser feitas, e dentro de que sistemas metafísicos são construídas"113. Assim, como entende Hodge, o perguntar metafísico e o perguntar ético se interpenetram, embora, na medida em que evoluem sejam expostos a pressões que tendem à exclusão de um ou de outro.

Interrogando o ente na direção de seu ser, indo além $(\mu \varepsilon \tau \alpha)$ do ente ( $\varphi$ vis), como o próprio nome já diz, a metafísica busca a essência do ente, o "quê" do ente, a entidade (Seiendheit) do ente ${ }^{114}$, e o faz tendo em mira uma perspectiva: o tempo. Dito de maneira mais esquemática, o ente, ou mais precisamente, o ser do ente é pensado como presentidade (Anwesenheit) e, por conseguinte, o próprio ser pensado como presença (Anwesen) e presença do que está presente. Este é um perigo para o qual nos alerta Vattimo:

O que torna o pensamento metafísico ‘dejecto' não é o facto de o ser se dar como presença, mas a petrificação da presença na

111 DANIEL, P. op. cit. p. 13-14.

112 Cf. HODGE, J. op. cit. p. 43.

${ }^{113}$ Cf. HODGE, J. op. cit. p. 12.

114 Cf. BOUTOT, Alain. Introdução à Filosofia de Heidegger. Portugal: Publicações Europa-América, 1991, p. 75. 
objetividade. Pode acolher-se a presença sem a petrificar na objetividade; e isto enquanto se recorda a presença no seu caráter de Anwesen-lassen, isto é, como acontecimento do desvelarse, como a-léthéia ${ }^{115}$.

Ao ser, como já vimos, não restou outra saída senão cair nas malhas do esquecimento. O que é pensado é o ser do ente, enquanto é pensado o ente como tal; em outras palavras, o ser enquanto ser, o ser em sua verdade, fica inquestionado pela metafísica, sendo interrogado apenas enquanto ilumina o ente. O próprio Heidegger nos esclarece:

A luz, isto é, aquilo que tal pensamento experimenta como luz, não é em si mesma objeto de análise; pois este pensamento analisa e representa continuamente e apenas o ente sob o ponto de vista do ente. É, sem dúvida, sob este ponto de vista que o pensamento metafísico pergunta pelas origens ônticas e por uma causa da luz. A luz mesma vale como suficientemente esclarecida pelo fato de garantir transparência a cada ponto de vista sobre o ente ${ }^{116}$.

Portanto, interessa ao perguntar metafísico, a presentabilidade do ente, aquilo que o ente é. Interessa ao perguntar técnico-científico, herdeiro do trono do logos metafísico, a soma do que é presentável, calculável, manipulável, objetivável ou, nas palavras de Loparic, "dável". Outras questões, as que não casam com o estatuto técnico-científico são simplesmente tidas como sem-sentido e, por isso, descartadas. Esta é a "sina metafísica" ou a errância atualizada do esquecimento do ser.

Pensar o ser como presença pensar o ente como presente é tornar estéril qualquer outra possibilidade de pensamento que não esteja na esfera da racionalidade - aquela que coloca ser e ente sob o mesmo invólucro, que coloca o ser como ser-representado submetido inteiramente ao sujeito-representante. E, como enfatiza Vattimo: "Re-

115 VATTIMO, Gianni. As Aventuras da Diferença: o que significa pensar depois de Heidegger e Nietzsche. p. 125.

116 HEIDEGGER, M. em sua Introdução (1949) a O que é metafísica? (1929). p. 253. (Grifos nossos). 
presentado não significa, naturalmente, imaginado, fantasiado, sonhado, mas trazido à consciência, ao ser, mediante procedimentos rigorosos, como os da ciência experimental e da técnica, que não só deles depende, mas que a funda na sua próxima possibilidade"117. Pensar o ser como presença do que está meramente presente, impede aquele modo de desvelamento que encontramos "no sentido grego da poiesis, sem controlar nada e ninguém, apenas deixa que as coisas sejam e se manifestem"118.

Assim, consideramos que o modo como Heidegger interroga o ser prepara o lugar a partir de onde se possa pensar uma nova ética, isto significa, não metafísica, ou seja, não orientada pela idéia de responsabilidade e de dever e agir morais, impostos pela razão à vontade. Nessa nova ética, o Dasein aparecerá como o lugar da interrogação do ser pelo ser, cabendo a ele apenas uma coisa: a respostabilidade ao apelo ser e, consequentemente, ao ter-que-ser, como veremos em nosso terceiro capítulo.

A dimensão de uma "meta-ética" no pensamento heideggeriano diz respeito, pois, à capacidade de ver mais além do que está simplesmente presente, que não se deixa aprisionar ao "quê" da metafísica, uma ética, digamos, que mantém uma origem ontológica. Foi por deixar escapar o "como" nas suas especulações sobre o ser dos entes, que a metafísica esqueceu a pergunta que ela mesma formulou, deixando esquecida também a sua essência. Nas palavras de Ernildo Stein:

Ora, justamente esse como, de onde se dá a totalidade do nosso compreender (...) não se resolve com o pensamento objetivador, com o pensamento que considera que o fundamento do conhecimento empírico é outro objeto, por mais universal que seja. Portanto, podemos dizer que o que falta em Aristóteles são os meios. Estes meios são o como para resolver os problemas filosóficos

117 VATTIMO, G. As Aventuras da Diferença: o que significa pensar depois de Heidegger e Nietzsche. p. 120.

${ }^{118}$ LOPARIC. Zejlko. O Fim da Metafísica em Carnap e Heidegger. In: De Boni. Luis A. (Org.). Finitude e Transcendência. Festschrift em Homenagem a Ernildo J. Stein. p. 793. Cf. também, HEIDEGGER, M. La Question de la Techinique. In: Essais et Conférences. p. 37. 
que ele havia percebido. Faltam os meios, falta o como, falta o método na sua ontologia ${ }^{119}$.

Heidegger vem nos apresentar, pois, um novo modo de pensar o ser, um modo, como diz Loparic, que "não reduz todo perguntar significativo ao perguntar científico"120, ao perguntar metafísico. Ou, como Vattimo: "Deve ser, portanto, um modo de pensar o ser que, sem o tornar presente como algo de presente, consiga dar o 'salto' para além da ciência e da filosofia (...)”, isto é, para além da metafísica e do seu ocaso no domínio técnico do mundo. Heidegger - tanto o Primeiro como o Segundo - empenhou-se nesta tarefa ou, mais apropriadamente, neste comprometimento de uma ética para com a questão do ser.

Assim, pensamos que o "como" da interrogação ética preconizada por Hodge diz respeito ao "como" da fenomenologia heideggeriana, ao que o Primeiro Heidegger chama de "compreensão prévia do ser" que se mantém em toda e qualquer possibilidade de investigação. A tentativa de sua ontologia fundamental nada mais é do que a experiência nova de pensar o ser de forma não metafísica ${ }^{121}$. O que significa dizer que, enquanto a ontologia tradicional pretende responder aos "quês" e "porquês" dos entes, achando mil respostas e perdendo-se em tantas outras, o Heidegger de Ser e tempo propõe uma questão prévia, a sua questão fundamental (Grundfrage), "o que há com o ser?", "qual o sentido do ser?" e, com essa questão, as bases dos "porquês" ficam abaladas, uma vez que o ser não é uma "essência", uma "razão", um "fundamento" no sentido de determinar "soluções"122 eficientes. Sobre isso, falaremos em nosso segundo capítulo.

119 STEIN, Ernildo. A caminho de uma fundamentação pós-metafísica. Porto Alegre: EDIPUCRS, 1997. p. 82.

${ }^{120}$ LOPARIC. Z. O Fim da Metafísica em Carnap e Heidegger. p. 797.

121 "Este interrogar deve pensar metafisicamente e, ao mesmo tempo, deve pensar a partir dos fundamentos da metafísica, vale dizer, não mais metafisicamente. Num sentido essencial, tal questionar permanece ambivalente". HEIDEGGER, M. no seu Posfácio de 1943 acrescentado a Que é Metafísica.(1929). p. 245.

${ }^{122}$ Cf. HAAR, Michel, Heidegger e a Essência do Homem. Trad. Ana Cristina Alves. Lisboa: Instituto Piaget, 1997. p. 149. 
O que sabemos é que a necessidade e a primazia da questão fundamental "qual o sentido do ser?" é de tal modo incontornável e anterior a toda lógica, que já está desde sempre posta ${ }^{123}$. Trata-se de um questionar essencial que exige para si uma lógica própria, diríamos, uma lógica originária e só a partir dela é possível reexaminar a questão do ser. Trata-se de um perguntar que extrapola os poderes da razão e aí encontram-se legitimadas as indagações de Panis:

Saber que não se pode e que não se poderá jamais responder a uma questão é uma razão suficiente para não colocá-la? A impossibilidade da resposta leva a uma impossibilidade da questão? A impossibilidade de resposta elimina a necessidade da questão? Questionar significa sempre saber responder? ${ }^{124}$

O autor, muito oportunamente, faz-nos lembrar o que o próprio Heidegger pensa a respeito: "Saber investigar significa saber esperar, mesmo que seja durante toda uma vida", lembra o nosso Filósofo em sua Introdução à Metafísica ${ }^{125}$.

É sobre essa temática, sobre essa lógica originária, "sem razão" de ser, "infundada", diríamos, "irreprésentável"126, em torno da questão do ser, que refletiremos a partir de agora.

${ }^{123}$ Id. ibid. cf. p. 149.

124 PANIS, Daniel. op. cit. p. 14.

${ }^{125}$ HEIDEGGER, M. Introdução à Metafísica. p. 227.

126 "Mas irrepresentável não quer dizer impensável, se é verdade que a representação não esgota o pensamento". HEIDEGGER, M. La Principe de raison. p. 72 